\title{
ROMANIA'S ROLE IN THE MANAGEMENT OF SECURITY ORGANIZATIONS
}

\author{
Florian RĂPAN*, Ioana Raluca GOLDBACH** \\ *"Dimitrie Cantemir" Christian University, Bucharest, Romania \\ **"Nicolae Balcescu" Land Forces Academy, Sibiu, Romania \\ rapan_florian@yahoo.com, ioanagoldbach@yahoo.com
}

\begin{abstract}
The disappearance of bipolarity causes essential mutations in the international security environment, which highlights the need to rethink the defence concept. The analysis of new risks and threats to international security has led to a new perception of it and has imposed a new orientation in the field of defence. The formation of new partnerships and alliances greatly reduces the likelihood of a conflict between members, which contributes to supporting the common interest of countries to maintain and strengthen international peace and security. All countries of the world are, in principle, members of at least one regional or intergovernmental organization. Although traditionally regional organizations have been set up on the basis of political, economical or environmental objectives, they have also entered security in recent decades and have started to develop their own capabilities to prevent conflicts and support peacekeeping operations or post-conflict construction of states.
\end{abstract}

Keywords: security environment, security organizations, alliances, The United Nations, European Union

\section{Preliminaries of Romania's participation in political-military alliances}

After the end of the Second World Conflict, for Romania as a Central European country in the Soviet sphere, the CSCE / OSCE was the only pan-European forum for political dialogue, an indispensable framework for examining security issues in conditions of equality with all other participating States[1].

On May 14, 1955, the Warsaw Pact was signed in Poland (Warsaw), a document that legislated the creation of a military alliance of the countries of Eastern Europe and the Eastern Bloc, unofficially called the "Friendship Treaty, cooperation and mutual assistance".

The Alliance, in which Romania participated until it ceased to exist on March 3rd 1991 (formally dissolved at the
Prague meeting of 1 July 1991), was created to protect the Member States against the perceived threat from the North Atlantic Alliance. By the Warsaw Pact, its members had committed themselves to mutually defending each other if one or more of them were attacked. It also provided for the signatories to base their relations on the principle of nonintervention in domestic affairs and on respect for national independence and sovereignty, a principle which was later violated in the case of the interventions in Hungary (1956) and Czechoslovakia (1968). It is worth mentioning that NATO and the Warsaw Pact have never entered a direct armed conflict, but between the two alliances there has been a "cold war" that has lasted over 35 years.

Although he had formally expressed his desire to become a UN member since 1946, 
on December 14, 1955, Romania, together with 15 other states, became a member of the United Nations on the basis of Resolution no. 955 (X) of the UN General Assembly [2].

"After the collapse of communism and the disappearance of the bipolar equation of international life, Romania has found itself in a changed geopolitical space" [3].Under these circumstances, our country has chosen as a solution to protect and strengthen national security joining NATO and thus on March 29, 2004, officially became a full member state of the North Atlantic Treaty Organization under the Washington Treaty, which states that from the legal point of view, the timing of the deposit of the instruments of ratification of the NATO accession protocol is equivalent to effective adherence.

At the same time, Romania has also chosen to join the European Union, becoming a member state on January 1st 2007. Accession to the EU meant for Romania, from the point of view of state security, the moment when it became both an active beneficiary as well as passive, of the Union's Common Foreign and Security Policy. As far as relations with the European Community are concerned, it is worth mentioning that our country "was the first Central and Eastern European country to have official relations with the European Community"[4].

\section{Romania's membership in international bodies - the main element of the security strategy}

Major political changes that characterize the beginning of the 21 st century have a major influence on European and EuroAtlantic security systems. As a result of the change in the protagonists 'commitment to playing roles but also of the increasing strategic partnership reconfiguration trends in accordance with the states' security objectives and interests, we can notice that the hierarchy of power centres has experienced a significant change. Under these circumstances, the National Defence
Strategy (SNAp) was designed in such a way that Romania can respond to the current requirements and challenges of the security environment as a member of the North Atlantic Alliance and of the European Union: "From this perspective, national security objectives and directions aim at strengthening national military and civil capabilities to standards that allow prevention, deterrence and defence against any aggressive actions against our country. Romania's active participation in collective defence within NATO, the implementation of the solidarity and mutual assistance clause in accordance with the provisions of the Treaty of Lisbon of the European Union and the development of the European Security and Defence Policy and the operations related to the assurance of the European area of freedom, security and justice are of equal importance "[5].

The current strategy is: multidimensional because other dimensions, very important as political, social, economic or ecological, multidirectional - security issues can also be vulnerabilities or threats and multifunctionality - are added to the military dimension - by the fact that it uses an extensive range of instruments including military force, information services, diplomacy and economic assistance.

The factors responsible for protecting and improving the national security of Romania have understood that the elements that make up the security matrix should not lack integrated security management and the idea of a security community.

The concept of a security community is unique to European states, with a national and international valence. National valence means integrated management of the country's defence, in which state institutions start from a common goal and help or complement each other to achieve it. At the same time, international valence implies multilateral security management and is achieved through co-operation within international organizations or coalitions.

To protect national interests, this strategy sets out several national security objectives, 
of which it is worth mentioning:

- the defence and promotion of human rights and the strengthening of international law principles as the foundations of international stability and security;

- ensuring a climate of peace, stability and security in the vicinity of Romania;

- ensuring an armed defence capability required to guarantee national interests and to comply with international obligations arising from membership of NATO and the EU;

- increasing the international influence of NATO and the EU in parallel with the strengthening of their cooperation as well as that between the USA and the European allies.

Taking into consideration the current situation of the international security environment and its possible evolution in the near future, Romanian experts identified more risks and threats to us, specifying the main ones of the National Defence Strategy:

- expanding the ways of manifestation of the terrorist phenomenon at international level and the emergence of new risks generated by religious radicalization, cyber terrorism or propaganda in the virtual environment;

- proliferation of weapons of mass destruction and development of ballistic missile programs;

- the emergence of state or non-state entities capable of acquiring some weapons production capacity for mass destruction;

- organized crime;

- trafficking and drug use;

- maintaining a high level of instability and insecurity in the Black Sea area;

- perpetuating uncertainties in the Western Balkans;

- the fragility of the international financial system;

- spying and other hostile actions of information services, informative activities and concerns of non-state actors aimed at influencing decision-making, including political decision-making, the media or public opinion;
- proliferation of radical, irredentist or extremist manifestations that may affect citizens' rights and freedoms, social cohesion or interethnic relations; - public health risks, pandemics;

- environmental degradation and natural disasters, including those caused by climate change.

Based on the established objectives and the identified risks to the national security, Romania will therefore continue to assume its responsibilities as a NATO and EU member state: "The strategy is a moral and political duty, having given that in 2018 we will celebrate the centenary of the Union, and in 2019 Romania will take over for the first time the presidency of the Council of the European Union, more than a decade after the actual accession "[6].

As a NATO member state, Romania's objectives respond to the national interests of the country and can be defined as follows [7]:

- a robust and relevant alliance, based on a solid transatlantic partnership;

- fulfilling the responsibilities of NATO member for participation in Alliance operations and missions;

- promoting the role of NATO as a stability provider, promoter of reforms and regional cooperation in the immediate neighbourhood of Romania (the Balkans and the Black Sea region);

- developing NATO partnerships with the EU and the UN;

- supporting the transformation process of NATO.

The signing of the Declaration on Ending the Support of the Joint Allied Forces Command in Naples for the Integration of the Romanian Armed Forces into the structures of the North Atlantic Alliance demonstrates that military achievements under the NATO accession and integration program are recognized and appreciated by the Alliance community and confirms the importance of the role that our country plays as a member state.

Cybernetics is now a very important aspect to be taken into account in the Security 
Matrix. In this respect, for Romania, the development of the information society is a fundamental objective in the medium and long term. By introducing new technologies, the development of the electronic alternative and the interconnection of the IT solutions have generated both advantages and some associated risks. As the frequency of cyberattacks is steadily increasing, the nature of the information exchanged requires an integrated approach. Under these circumstances, cooperation on the main lines of action at European and international level becomes essential, with the international community making every effort to respond to this new genderthreatening threat to national security and interest. In this context, NATO and Romania signed a Memorandum of Understanding on Cyber Security Cooperation in Brussels on October 18, 2011 which the NATO Secretary General's representative, as signatory of the North Atlantic Alliance document, considered it to be very important for both the organization and Romania at national level. The signing of the Memorandum is part of the actions envisaged for the implementation of the current NATO Strategic Concept adopted at the Lisbon Summit and formalizes the cooperation between Romania and the North Atlantic Alliance in this area in the field of information exchange, assistance or participation in joint activities.

Regarding the quality of EU member state, viewed through the protection and strengthening of national security, the National Defence Strategy clearly states that: "Regional cooperation, by strengthening the eastern and southern dimensions of the European Union's neighbourhood policies, importance"[8]. Romania benefits from the provisions of the Treaty of Lisbon, where EU objectives and values are clearly defined, and which guarantees the security of its citizens, supports and promotes the values of the Union throughout the world and contributes to the peace and sustainable development of the planet. At the same time, our country must participate in Union-led missions outside its territory for peacekeeping, conflict prevention and strengthening international security in the context of the UN Charter. As the EU is becoming more and more a global actor, its actions have a notable impact in areas of primacy for international stability. The Union has become recognized as an active participant in international crisis management, with an increasing capacity to act on foreign policy and security issues and also outstanding achievements. Therefore, we can state that Romania's membership of NATO and the EU as well as the international defence cooperation support the capacity and credibility of our country towards the national defence policy. By participating in managing global crises, Romania's security is improved and international interoperability is favoured.

As a member of the United Nations, Romania has the opportunity to participate in the decision-making process within the world organization, with influences on the international situation at a global level and in close geographic areas. Our country's participation in UN peacekeeping operations has highlighted over the years the efficiency of the Romanian army and Romania's political readiness to engage in multinational military activities to maintain international stability [9].

In relation to the OSCE, Romania's current priorities are in line with the EU's foreign and security policy objectives. Romania has a well-defined profile in the politicalmilitary field, supported by substantial contributions in the Vienna negotiations and consultations on topics of particular interest, focusing on conventional arms control (CFE) and confidence-building and confidence-building measures (CSBMs). Existing mechanisms in this area - the Convention on Conventional Armed Forces in Europe (CFE), the Vienna Confidence and Confidence Building Measures, the Open Skies Treaty, the Code of Conduct on 
Political and Military Security Issues - all form a solid acquits principles and commitments. Romania supports the maintenance, consolidation and modernization of this acquits, in parallel with the full implementation of all the commitments assumed within it. Both the conventional arms control regime and confidence building and security measures remain important tools to ensure military stability, predictability and transparency, in order to be fully operational, and these must be revitalized, updated and upgraded. Romania supports the process of updating the Vienna Document, being actively involved in negotiations in recent years. As a central message, Romania has promoted, on the agreed EU-wide line, a substantial update with a real potential to improve military transparency in the OSCE area. Romania supports the full implementation of the obligations of all participating States and advocates updating the Document, taking into account the lessons learned in the context of the crisis in Ukraine.

Romania held the rotating presidency of the Open Skies Consultative Commission (OSCC) between September and December 2016, which took place in Vienna. During the meetings, issues related to the implementation of the Open Skies Treaty were examined, such as the observance of treaty provisions by States Parties, the resolution of ambiguities and discrepancies in interpretation occurring during the implementation of the treaty, the accession of new states to the Treaty and the revision allocation of annual flight quotas.

At the OSCE Ministerial Council in Hamburg (8-9 December 2016), the Participating States welcomed the launch of a Structured Dialogue on Current and Future Security Challenges in the OSCE Area (MC.DOC / 4/16)[10].

Under the relationship of bilateral relations, Romania wants to develop a strategic partnership with the United States of America. On the basis of this partnership, on September 13, 2011, the two states signed an agreement that provides for the installation of an anti-missile defence system in our country, which is designed to protect against any attack with short- or medium-range missiles action, or, in the final, intercontinental phase. At the same time, Romania's foreign policy in relation to the eastern or south-eastern neighbourhood is based on solidarity and the capitalization of opportunities [11].

An equal importance to the eastern neighbourhood is also given to the Western Balkans, starting from the idea that our country needs, in its immediate neighbourhood, a stable and prosperous area. The strategic importance of the South Caucasus and Central Asia states remains high and, from this perspective, Romania's goal is to take advantage of the privileged relationship it has established with these countries.

We can say that Romania's security and defence interests are indissolubly linked to regional and global ones and the principle of unity of purpose in the dimensioning of forces and complementarity of common resources is an objective necessity in the future development of the process of full integration of Romania into NATO and the European Union. National interests must be linked to the Alliance's overall commitments and objectives and interlinked with those of the EU [12].

\section{Conclusions}

Conflicts of the 21 st century are, for the most part, part of the category of unconventional or low intensity forms. This tendency forces the international community to change its approach to security interests, and the current difficulties are more than obvious. Proper understanding of the complex implications of the current world order on national security policies, military defence strategies, and the structures of forces and their engagement are in itself an imperative for all states of the world. In this context, we appreciate globalization as a process of unlimited, ample and extremely complex duration, both through its positive and 
negative effects. No state, irrespective of its size, its level of economic development, its organizational and political leadership or its military power, can oppose or evade this process, the sense of human development seeming to lead to the achievement of a defined world community rather, through the interdependence relations between its members, rather than by the logic of national or group isolation.

Many of the contemporary issues, considered to be of global importance in terms of the purpose and the way to solve them, are determined by the interaction of economic, social, political, cultural, ecological or military processes and phenomena. Some of them are very serious problems, with an exponential dynamics on which the future of the planet depends, to an increasing extent. Only through common and equitable actions can we find adequate solutions to the great problems of the planet. The need for a unitary vision of collective security is determined by the need for effective action to prevent and respond to all major threats to international peace and security. A very important step in this direction is the formation of partnerships, alliances or coalitions between states.

\section{References}

[1] http://www.mae.ro/node/1981-1, accessed on 10.01.2018

[2] http://www.mae.ro/node/1588, accessed on 10.01.2018

[3] Constantin, Hlihor, România şi vecinătatea sa după încheierea Războiului Rece, Analele Universităţii Creştine „Dimitrie Cantemir”, Seria Istorie, Nr.1, Bucureşti, 2010, p. 186.

[4] http://en.wikipedia.org/wiki/Integrarea_Rom\%C3\%A2niei_\%C3\%AEn_Uniunea_Euro pean $\% \mathrm{C} 4 \% 83$, accessed on 10.01 .2018

[5] Strategia Naţională de Apărare a Ţării pentru perioada 2015-2019, Bucureşti, 2015, p. 6

[6] Ibidem, p. 6

[7] http://www.mae.ro/node/5339, accessed on 10.01.2018

[8] Strategia Naţională de Apărare a Țării pentru perioada 2015-2019, Bucureşti, 2015, p. 13

[9] http://mpnewyork.mae.ro/node/679, accessed on 10.01 .2018

[10] http://www.mae.ro/node/2114, accessed on 10.01.2018

[11] Florian Răpan, Claudiu Marin Bibiriţă, Managementul organizaţiilor de securitate, Editura ProUniversitaria, Bucureşti, 2014

[12] Strategia Naţională de Apărare a Țării pentru perioada 2015 - 2019 - O Românie puternică în Europa şi în lume, Bucureşti, 2015. 